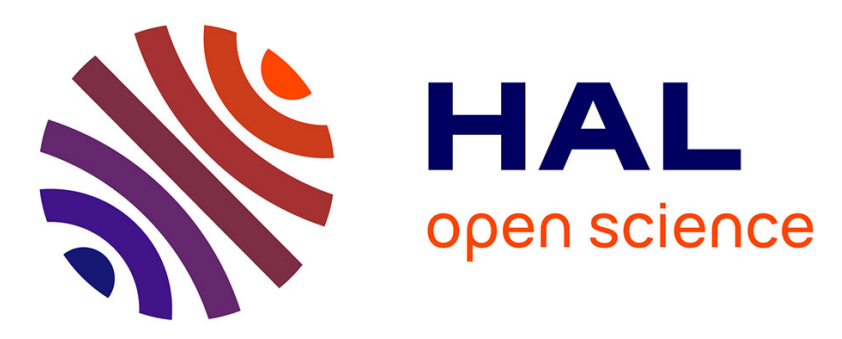

\title{
The hydrological impact of the mediterranean forest: a review of French research
}

\author{
Claude Cosandey, Vazken Andréassian, Claude Martin, Jean-François \\ Didon-Lescot, Jacques Lavabre, Nathalie Folton, Nicolle Mathys, Didier \\ Richard
}

\section{To cite this version:}

Claude Cosandey, Vazken Andréassian, Claude Martin, Jean-François Didon-Lescot, Jacques Lavabre, et al.. The hydrological impact of the mediterranean forest: a review of French research. Journal of Hydrology, 2005, 301 (4), pp.235-249. hal-00327222

\section{HAL Id: hal-00327222 \\ https://hal.science/hal-00327222}

Submitted on 7 Oct 2008

HAL is a multi-disciplinary open access archive for the deposit and dissemination of scientific research documents, whether they are published or not. The documents may come from teaching and research institutions in France or abroad, or from public or private research centers.
L'archive ouverte pluridisciplinaire HAL, est destinée au dépôt et à la diffusion de documents scientifiques de niveau recherche, publiés ou non, émanant des établissements d'enseignement et de recherche français ou étrangers, des laboratoires publics ou privés. 


\title{
The hydrological impact of the mediterranean forest: a review of French research
}

\author{
Claude Cosandey* ; Vasken Andréassian** ; Claude Martin*** ; JF Didon-Lescot*** \\ Jacques Lavabre **** ; Nathalie Folton $* * * *$; Nicolle Mathys***** ; Didier Richard*****
}

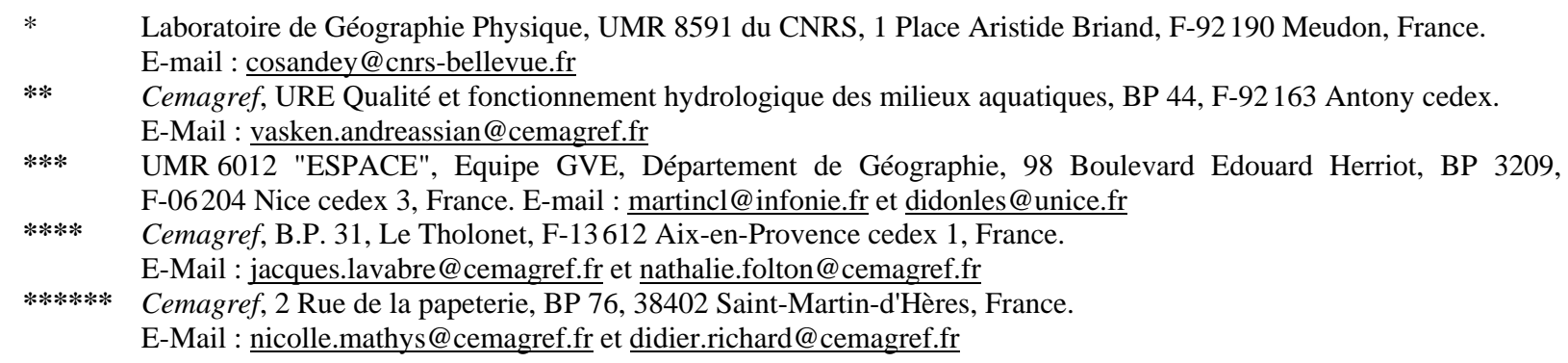

\begin{abstract}
Forest hydrology studies carried out in France have focused mainly on the Mediterranean part of the country. Three experimental catchments groups exist and have been monitored over a long period. Some forested catchment (Draix catchment) underwent no change during the study period, while others experienced either clear cutting (Lozère catchment) or forest fires (part of the Réal Collobrier catchments). In each case studied, the behaviour of the forested catchment was compared to that of a control catchment.

Included with the experimental catchments studies are the results of research with a fundamentally different approach. The research is based on a statistical study of the interrelated development of afforestation rates and runoff characteristics for average-sized catchments (around $100 \mathrm{~km}^{2}$ ) in that part of the southern French Massif Central which is subject to Mediterranean rainfall conditions.

The results differ considerably from one site to another, indicating the degree of complexity of the rainfall/discharge relationship. An increase in extreme flood events due to forest disturbance could by no means be confirmed in every case. A closer look at the hydrological behaviour of the catchments cleared up the apparent inconsistencies. It is mainly the contrast between bare soil and vegetated soil, rather than between forest and other types of vegetation witch is relevant in explaining the hydrological behaviour.
\end{abstract}

Keywords: Forest hydrology; Floods; Annual discharge; Mediterranean climate.

\section{1 - Introduction}

There is much controversy about the hydrological impact of forests with respect to flood events, low flows, and even annual runoff (Bosch and Hewlett, 1982; Bruinjzeel, 1990; Fritsch, 1992; Calder, 1998). It is true that the influence of forest on flows depends on a large number of factors, which explains the widely dissimilar results observed.

In the South of France, research on the subject focused on three research catchments in the humid Mediterranean zone. The sites differ in pedological and geomorphological characteristics, although all three are subject to heavy rainfall in autumn and sometimes during the summer. The wide variety of responses observed prompted an attempt to isolate the hydrological mechanisms that would explain the effect of plant cover on catchment hydrological behaviour. 


\section{2 - Study sites and experimental conditions}

The three sites chosen for study were the Draix basin, situated on the black marls of the Digne area in the Provençal hinterland; the Réal Collobrier basin located close to the shores of the Mediterranean; and the Mont-Lozère basin in the south-eastern foothills of the Massif Central (Fig. 1).

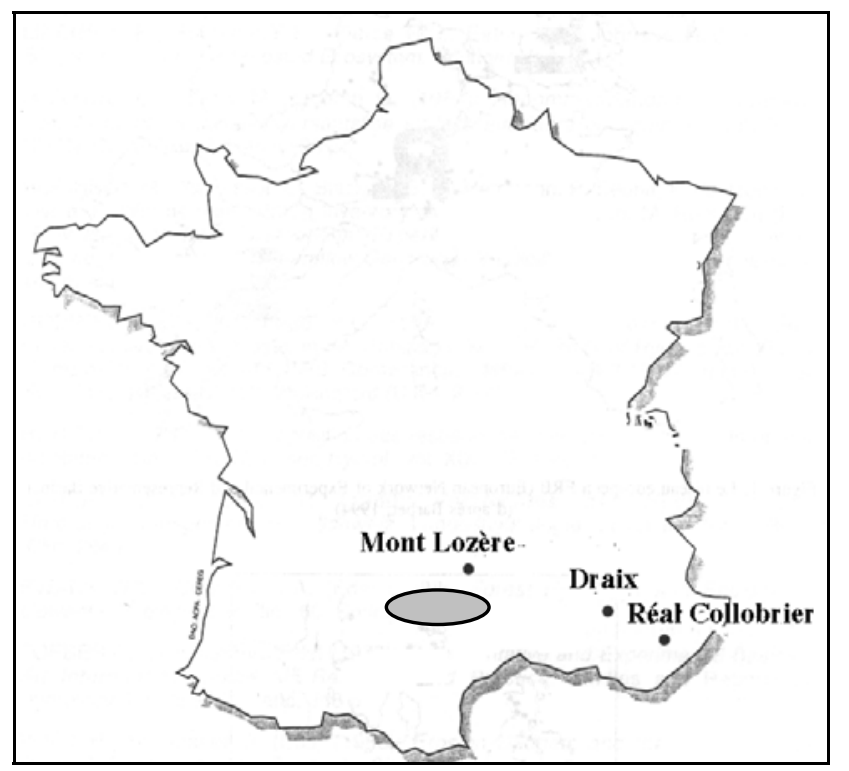

Figure 1 - Sites of forest hydrology research in Mediterranean France (Catchments studied in the Southern Massif Central are indicated in grey).

The main site characteristics are shown below in Table 1:

Table 1 - Main site characteristics.

\begin{tabular}{|c|c|c|c|c|}
\hline Catchment & Area & Land Use & $\begin{array}{l}\text { Mean slope } \\
\text { value }\end{array}$ & Study Period \\
\hline \multicolumn{5}{|l|}{ Draix } \\
\hline Laval & $0.86 \mathrm{~km}^{2}$ & $\begin{array}{l}22 \% \text { bush and woodland (from } 10 \text { to } 100 \\
\text { years old) } ; 10 \% \text { grassland; } 68 \% \text { bare soils }\end{array}$ & $58 \%$ & $1983-2000$ \\
\hline Brusquet & $1.08 \mathrm{~km}^{2}$ & $\begin{array}{l}87 \% \text { woodland (plantation, } 100-120 \text { years old); } \\
13 \% \text { bare ground }\end{array}$ & $53 \%$ & $1983-2000$ \\
\hline \multicolumn{5}{|l|}{ Réal Collobrier } \\
\hline Rimbaud & & $\begin{array}{l}\text { Maquis shrubland; fire; } \\
\text { regrowth of maquis }\end{array}$ & $20 \%$ & $\begin{array}{l}1968-1990 \\
1990-2000\end{array}$ \\
\hline Valescure & $9.30 \mathrm{~km}^{2}$ & Maquis & & $1968-2000$ \\
\hline \multicolumn{5}{|l|}{ Mont-Lozère } \\
\hline Latte & $0.20 \mathrm{~km}^{2}$ & $\begin{array}{l}\text { Spruce (plantation, } 70 \text { years old); cutting; } \\
\text { regrowth }\end{array}$ & $20 \%$ & $\begin{array}{l}1981-1987 ; \\
1987-1999\end{array}$ \\
\hline Cloutasses & $0.81 \mathrm{~km}^{2}$ & Pasture & $10 \%$ & $1981-1999$ \\
\hline Sapine & $0.54 \mathrm{~km}^{2}$ & Natural beech forest (100 years old) & $18 \%$ & $1982-1999$ \\
\hline
\end{tabular}

These three groups of catchments have not been managed with the same objective, and forest hydrology did not necessarily play a major role in setting them up. Therefore, it is not surprising that the methods differed for each independently conducted study: 
* The Draix catchments are located on land (Oxfordian black marls) with major erosion problems due principally to the fact that the rock (black marls) is very susceptible to erosion. Erosion induces steep slopes. The question remains on the origin of the erosion: incision of the main stream, deforestation at the early age of human occupation.

The main objective there was to estimate the protective role of the forest within the framework of a national soil conservation project. The experimental set-up consists of two catchments: one (the Brusquet) that was re-afforested towards the end of the nineteenth century. The stands on the Brusquet are classified as 'conservation forest' by the French Forest Service, and as such, have been left untouched for the last 100 years; The second (the Laval) was an un-afforested one where vegetation cover is sparse (see Table 1). Here the comparative catchments method was used. Mean annual rainfall is about $940 \mathrm{~mm}$, with decadal daily maxima of $80 \mathrm{~mm}$, and heavy summer and autumn rainstorms.

* The objective on the Réal Collobrier catchments was a broader study of the hydrological behaviour of small Mediterranean catchments on metamorphic substratum (gneiss, mica schists, phyllites) with rather thin ranker soils (no more than $30 \mathrm{~cm}$. on the Rimbaud catchment). After 25 years of monitoring, a wild fire destroyed more than $75 \%$ of the plant cover on the Rimbaud catchment, providing an opportunity to study the hydrological impact of forest destruction. The data used here concern the Rimbaud catchment before and after the forest fire, compared to the unchanged Valescure catchment (Table 1). So the paired catchment method is used here. Mean annual rainfall is about $1200 \mathrm{~mm}$, with decadal daily maxima of $150 \mathrm{~mm}$.

* The Mont-Lozère catchments are located on thin, permeable granitic soil - usually less than a metre thick. They were set up to study the hydrologic behaviour of catchments, as similar as possible and differing only for land cover (grassland, beech forest, and spruce forest). For all types of vegetation, the ground is well covered, except for few gullies on the grassland catchment. The data used here concern the grassland (the Cloutasses) and coniferous (the Latte) catchments. After six years of measurement, the forested Latte catchment was attacked by parasites and the Forest Service proceeded with clear-cutting. The experimental catchment method was also used here: the data obtained on this catchment before and after the cut was compared to data from the Cloutasses control catchment. Rainfall is much more abundant than on the two previous catchments, due to an orographic influence on the moist Mediterranean winds (Mont-Lozère culminates at $1699 \mathrm{~m}$ ). Mean annual precipitation is $1950 \mathrm{~mm}$. Rainfall events can bring as much as $400 \mathrm{~mm}$ of rain within a 24-hour period.

\section{The effects of forest on floods}

The apparent impact of forest on floods (peaks or volume) differs considerably from one site to another.

\subsection{The Draix basin}

The soil in the Brusquet was badly eroded before the forest was planted to protect it in C19. The primary effect of plant cover is to raise the threshold for the amount of rain needed to initiate flow: the reforested catchment experiences fewer floods, and many showers produce no notable flow (Richard and Mathys, 1999). The present drainage density is greater on the Laval as many gullies are in denuded zones of the basin. In the Brusquet basin, the forest has completely hidden all the small gullies network (and many restoration works with small wood dams and so on were carried out before planting 100 years ago). When flooding occurs on both catchments, observations showed that flood peaks occur at least a half-hour later on the reforested Brusquet catchment (see above). Flood peaks on the unforested Laval catchment are particularly high, reaching $23 \mathrm{~m}^{3} \cdot \mathrm{s}^{-1} \cdot \mathrm{km}^{-2}$ during one 53-mm rainfall event; for that same event, the flood peak for the Brusquet catchment was only $2.3 \mathrm{~m}^{3} . \mathrm{s}^{-1} \cdot \mathrm{km}^{-2}$, or one-tenth as intense. Except for these extreme cases, most flood peaks for the wooded catchment have commonly represented one-fifth of those on the unforested Laval catchment. For an example, see the May 271988 flood shown in Figure 2. This result does not mean that forest reduce flood peaks by $80 \%$, but it is clear that the differences between the two basins are important, and mainly due to the reforestation - including relatively deep forest soils formation.

The denuded catchment responded to a storm that left $21 \mathrm{~mm}$ of rainfall on the Brusquet and $22 \mathrm{~mm}$ on the Laval in less than four hours. On the Laval, flood peak was $1.3 \mathrm{~m}^{3} \cdot \mathrm{s}^{-1} \cdot \mathrm{km}^{-2}$ and only $0.2 \mathrm{~m}^{3} . \mathrm{s}^{-1} \cdot \mathrm{km}^{-2}$ on the Brusquet, a ratio of 1-6. It is worthy of note, however, that for a few specific cases (the 08/09/87 and 5/11/94 floods), the ratio is only 1-2 (Combes et al., 1994), raising the question of the persistence of the impact of the forest in certain extreme situations. The reason is that initial conditions modify the threshold for runoff 
generation on the Brusquet, and long even high precipitation with moderate intensity generate less high peak flows on Laval.

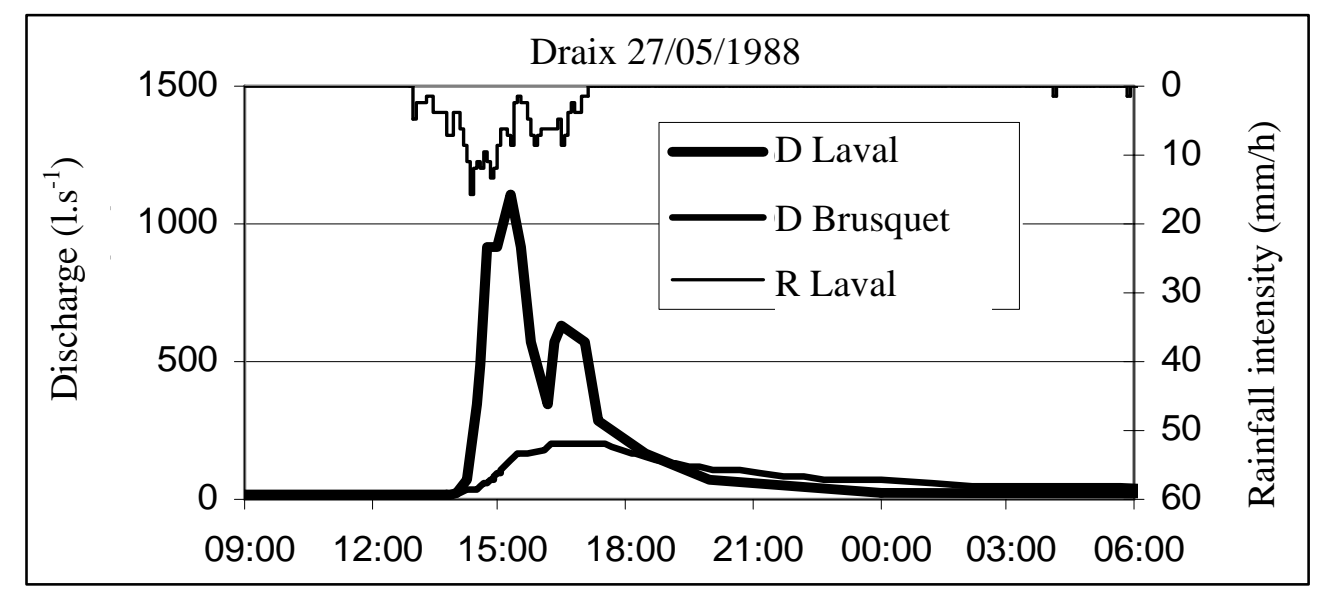

$\mathrm{D}$ : discharge. $\mathrm{R}$ : rainfall.

Figure 2 - The May 271988 flood on the Brusquet (reforested) and Laval (denuded) catchments.

Flood volumes were less limited than peak discharge, because the flood lasted longer on the forested catchment. In the example of the May 271988 flood, the depth of runoff was $10.9 \mathrm{~mm}$ on the Laval catchment and only 4.3 on the Brusquet; the runoff ratio during the flood was about 1-2.5; and overall flood volume on the Brusquet catchment was reduced by about half. Combes et al. (1994) attributed these differences in behaviour to the presence of forest soil, which plays a specific role in water storage.

\subsection{On the Réal Collobrier catchments}

In summer 1990, a forest fire destroyed more than $80 \%$ of the forest cover on the small Rimbaud catchment. That autumn, the Rimbaud stream behaved in a flashy fashion. The change in behaviour can be seen clearly in Figure 3, which plots the relationship of the instantaneous peak discharge registered in autumn with the corresponding rainfall within a 24-hours period.

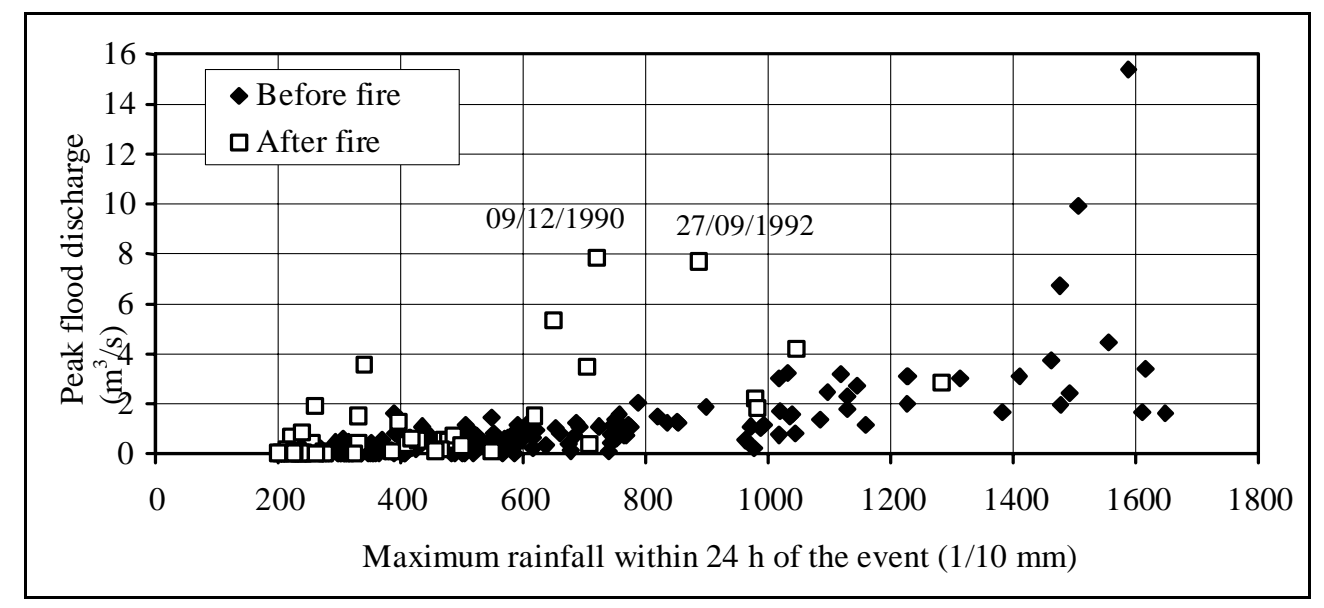

Figure 3 - Relationship throughout the autumn period (September, October, and November) between peak flood discharge and precipitation within 24 hours (period after the fire: September 1990 - November 1994).

Immediately after the fire, peak discharge reached $7.8 \mathrm{~m}^{3} \cdot \mathrm{s}^{-1}$ on December $9^{\text {th }}$ (a bit more than $5 \mathrm{~m}^{3} \cdot \mathrm{s}^{-1} \cdot \mathrm{km}^{-2}$ ) for rainfall events that were neither particularly abundant nor intense $(80 \mathrm{~mm}$, with peaks that did not exceed $40 \mathrm{~mm} / \mathrm{h}$ for a period of $6 \mathrm{~min}$.). Rising flood stages frequently lasted no more than five minutes, and 
recession was also very rapid. The extreme reactivity of the streams to precipitation was due to runoff on the slopes that had been denuded by the fire (Martin and Lavabre, 1997).

There was only one violent event the following year (1991-92), with $3.6 \mathrm{~m}^{3} . \mathrm{s}^{-1}$ in October, but there were several unusually large floods again in 1992-93 $\left(7.7 \mathrm{~m}^{3} . \mathrm{s}^{-1}\right.$ in September; $3.5 \mathrm{~m}^{3} . \mathrm{s}^{-1}$ in October, and $4.3 \mathrm{~m}^{3} . \mathrm{s}^{-1}$ in November), before plant regrowth was effective to bring back catchment behaviour to normal. The shrub cover rate on the burned surfaces were 15\% in August 1991, 30-35\% in August 1992, and 45-50\% in August 1993 (based in part on observations made by Puech et al., 1994, and Viné, 1997); in 1993-94, peak discharge did not exceed $2.2 \mathrm{~m}^{3} . \mathrm{s}^{-1}$. There were no data about the fact that the fire has changed the soil structure; it is possible that, for the first year, some surface modifications could contribute to explain the very important peak floods. But return to the initial behaviour was rapid: after four years, no more trace was left in the hydrological behaviour, which prove that there were not definitive modifications, and that the hydrological behaviour of the soil was not drastly changed by the burning.

However, the graph shows a large number of post-fire peak floods in the cluster of points that represent the pre-fire floods. Different studies show in fact that the response to heavy rain is particularly violent after a fire (Lavabre et al., 1997), while longer-lasting, gentler frontal rainfall causes very much the same flood response both before and after forest fire. Therefore, it appears that the hydrological behaviour of catchments after fire is significantly different only briefly and during heavy rainfall events, which results into an increase in peak discharge for certain floods without significant increase in flood volumes. This is borne out by a close look at the annual water balances, where the impact of the forest fire is hardly noticeable (within the tolerances of the measuring methods and models used).

\subsection{The Mont-Lozère basin}

The Cevennes Mountain rainfall characteristics (dangerous storms, flash floods) make for extremely difficult working conditions, and it is difficult to establish totally reliable stage-discharge relationships. Comparing peak discharge on grassland catchments (Cloutasses) with that of forested catchments (Latte) is not an easy task.

Lavabre and Martin. (1999) and Lavabre et al. (1999) made one attempt that used 48 flood events selected from 16 years of observation statistics to determine discharge for annual and decadal return periods, using Hazen's formula (Hazen, 1930). According to these calculations, annual peak discharge was $1 \mathrm{~m}^{3} \cdot \mathrm{s}^{-1} \cdot \mathrm{km}^{-2}$ for the Latte catchment and $1.45 \mathrm{~m}^{3} \cdot \mathrm{s}^{-1} \cdot \mathrm{km}^{-2}$ for the Cloutasses catchment, indicating a slight reduction in peak floods for the forested Latte catchment. The decadal discharge, however, was $3.15 \mathrm{~m}^{3} \cdot \mathrm{s}^{-1} \cdot \mathrm{km}^{-2}$ for the Latte and only $3 \mathrm{~m}^{3} . \mathrm{s}^{-1} \cdot \mathrm{km}^{-2}$ for the Cloutasses catchment, indicating that the forest slightly decreased annual flood, but had no further effect on decadal flood. This is a useful observation that is supported by other forest studies - the claim that 'forest reduce floods' is mainly true for small/medium hydrographs, but not for extreme events.

On the Latte catchment, forest was cut after six years of observation, providing another approach based on comparisons of discharge measured at the outlet of both catchments for two heavy flood events, one on November 5-7 1984 and the other, November 2-5 1994. The comparisons showed no significant change in catchment behaviour on the Latte as a consequence of the spruce cuts (Lavabre et al., 1999b). It is true that the forest health was poor before the cut (dendroctone - spruce beetle - attack, perhaps due to some sanitary problems, but not identified), but there was no major influence on hydrological behaviour, mainly because leaf area and interception was not reduced.

During the November 1984 event ( $\mathrm{P}=350 \mathrm{~mm}$ over 72 hours) and following a weaker initial response than on the other two catchments, the forested Latte catchment had the highest specific peak discharge: $1 \mathrm{~m}^{3} \cdot \mathrm{s}^{-1} \cdot \mathrm{km}^{-2}$, compared to $1.8 \mathrm{~m}^{3} \cdot \mathrm{s}^{-1} \cdot \mathrm{km}^{-2}$ for the Cloutasses. In November $1994(\mathrm{P}=431 \mathrm{~mm}$ within 4 days, including $408 \mathrm{~mm}$ between November $3^{\text {rd }}$ and $5^{\text {th }}$ ), the Latte catchment's response was also slightly slower than on the other two catchments, and the peak discharge was $3.1 \mathrm{~m}^{3} \cdot \mathrm{s}^{-1} \cdot \mathrm{km}^{-2}$ on the Latte and $3 \mathrm{~m}^{3} \mathrm{~s}^{-1} \mathrm{~km}^{-2}$ on the Cloutasses. The November 1994 flood occurred well after the cut, however, during a period that possibly marked the Latte catchment's return to pre-cut behaviour (Martin et al., 2000), despite of the fact forest regrowth was quite negligible. 
While it is difficult to ascertain peak values, flood volumes are easier to estimate accurately. A double mass curve can be used to plot the values for daily runoff during heavy flood events on the Latte catchment (before and after cutting) against those for the Cloutasses catchment (considered as the control), providing information about any change in the relationship between the two catchments. The curve uses data from those days when the depth of runoff on the Cloutasses catchment was greater than $30 \mathrm{~mm}$ (Fig. 4). Runoff of this magnitude occurs less than eight times per year on the average, although they account for more than onefifth of total runoff (21.8\% - Martin et al., 2000).

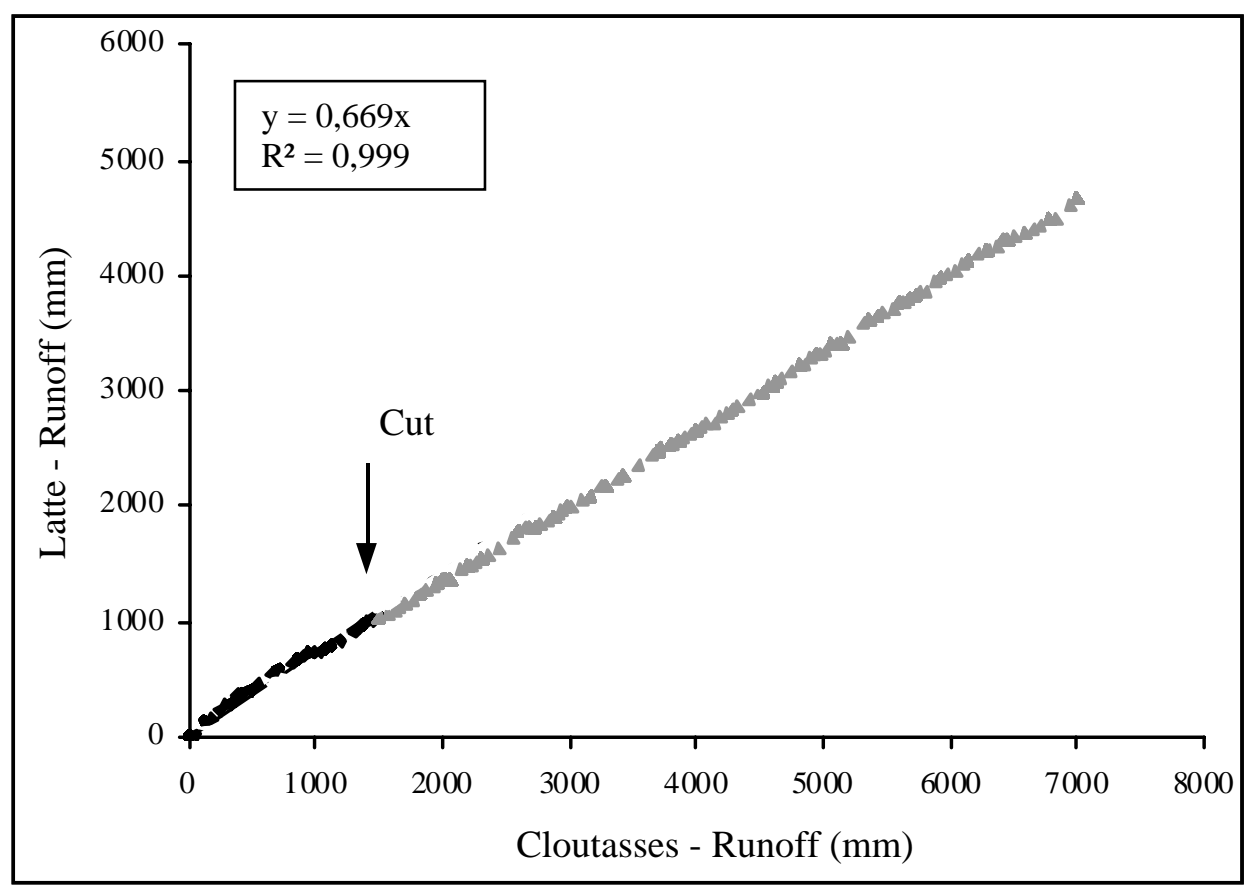

Figure 4 - Double mass curve for runoff on the Latte and Cloutasses catchments during extreme flood events.

This figure does not show a break that would indicate any change in catchment behaviour on the Latte in connection with the cuts. That result does show up when a lower threshold is used, since another study of the same type based on discharge over $20 \mathrm{~mm} /$ day on the Latte catchment led to identical conclusions (Cosandey et al., 2000). So the spruce cuts apparently did not cause higher runoff during heavy flood events, due to the highly permeable soils and the specific flood-forming processes (Cosandey, 1994).

It must be noted that the research done by Cognard-Plancq et al. (2001) reached different conclusions, specifically that the forest cuts caused a 9-13\% increase in flood discharge, even the highest ones. However, the approach used (global modelling of rainfall/discharge relationships) did not allow distinguishing heavy and light flood events. Therefore, it is not surprising that, due to the heavy impact of the cut on the less severe flood events (as result of the decrease in interception losses, the importance of which was demonstrated by Cosandey et al., 2001), this approach draws attention to the overall trend towards an increase in runoff for flood events as a whole.

\section{4 - The effects of forest vegetation on annual runoff}

\subsection{At Draix}

Beginning of the active erosion phase in date 8000 BP (Ballais, 1997) and the origin of this erosion is not well known. It is usually assessed that overgrazing and bad farming practices from the middle age to now increased this phenomena. The guiding issue for setting up the Draix catchments was the study of erosion, 
and, for this reason, measuring techniques have been based mainly on the observation of extreme events. Imprecise measurement of the low-water levels has prevented obtaining reliable estimates of annual runoff.

We have seen that flood flows were much higher on the forested catchment. However, it is clear that the water stored there serves to supply the forest, and therefore is lost for runoff purposes. Field observations also show that the period without flow is shorter on the denuded Laval catchment than on the forested Brusquet catchment. These observations may be surprising, but they can be explained by a combination of two different processes; i.e., although recession takes longer on the forested catchment where the soil is deeper, many more rainfall events give rise to runoff on the denuded catchment, due to the low permeability and small retention capacity of the soil there. The present drainage density is greater on the Laval as many gullies are in denuded zones of the basin. In the Brusquet basin, the forest has completely hidden all the small gullies network (and many restoration works with small wood dams and so on were carried out before planting 100 years ago).

Poiniard (2000) did make an attempt to fill in the gaps and correct questionable measurements by reconstructing the annual discharge for two characteristic years. He concluded that the runoff deficits were slightly higher (5 to $10 \%$ of incidental rainfall) for the forested catchment.

In the end, although it is not possible to give a reliable estimate of the differences, observations in the Draix basin showed that there was somewhat more loss through evapotranspiration and less annual runoff on the forested catchment than on the unforested one, even if the difference is only very slight.

\subsection{The Réal Collobrier basin}

Rainfall/discharge modelling (GR models) and several different statistical approaches were used in the study on the impact of the forest fire on the Rimbaud catchment. The runoff observed after the fire was compared with runoff established for the same period using equations or models based on:

1) rainfall/runoff ratios for the Rimbaud catchment from before the fire,

2) the ratio between runoff on the Rimbaud and runoff on the Valescure catchment, which had not suffered a fire (Lavabre et al., 2000).

Whether based on yearly (Fig. 5), monthly, or daily intervals, all modelling showed an increase in runoff after forest fire. Based on these analyses, the additional runoff during the three years following the fire can be estimated at about $100 \mathrm{~mm}$ (an increase of about 15\%). It must be noted, however, that these results are based on the Rimbaud catchment's only rain recorder, for which the stationarity appears to be questionable: the destruction of the plant cover around the collector probably affected its catch (Lavabre et al., 1999). Comparing the precipitation levels from the Rimbaud rain recorder with those from the other recorders in the Réal Collobrier networks is not conclusive enough (Fourcade, 2001). If one uses the rainfall data from the Valescure control catchment as a reference instead of the Rimbaud, however, the increase in runoff appears much less noticeable.

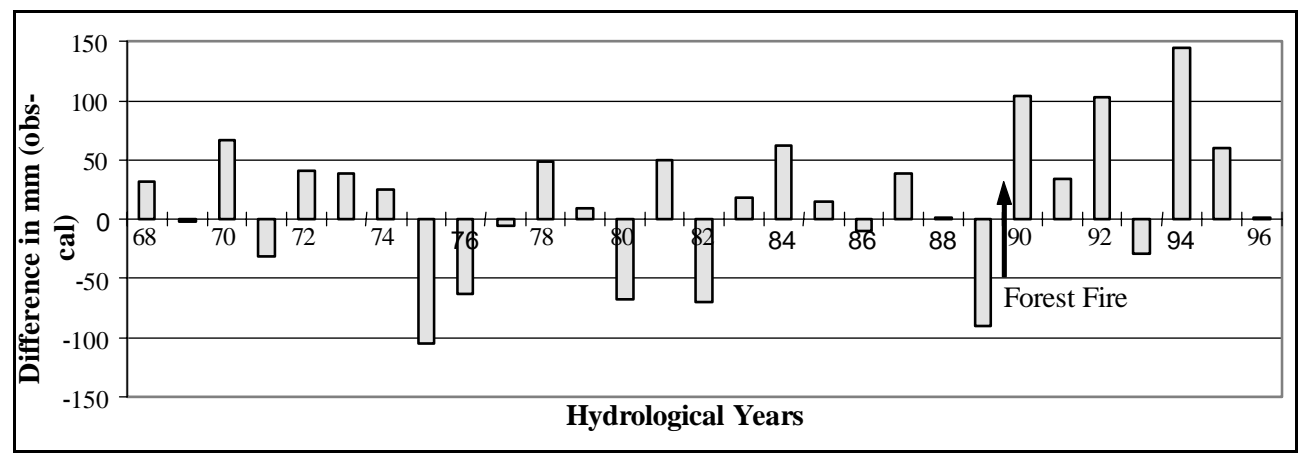

Figure 5 - The Rimbaud catchment: Differences between observed annual runoff and that calculated on the pre-fire rainfall/runoff ratio 
We can conclude that the impact of the fire on annual runoff was very limited on the Rimbaud catchment, which is located on solid rock and has very limited water storage. The results remained within the tolerances of measuring accuracy and the methods used.

\subsection{On Mont-Lozère}

When we compared the annual runoff for the catchments before and after the forest cuts (from July to June), we observed a perceptibly change after the cut, as shown in Figure 6.

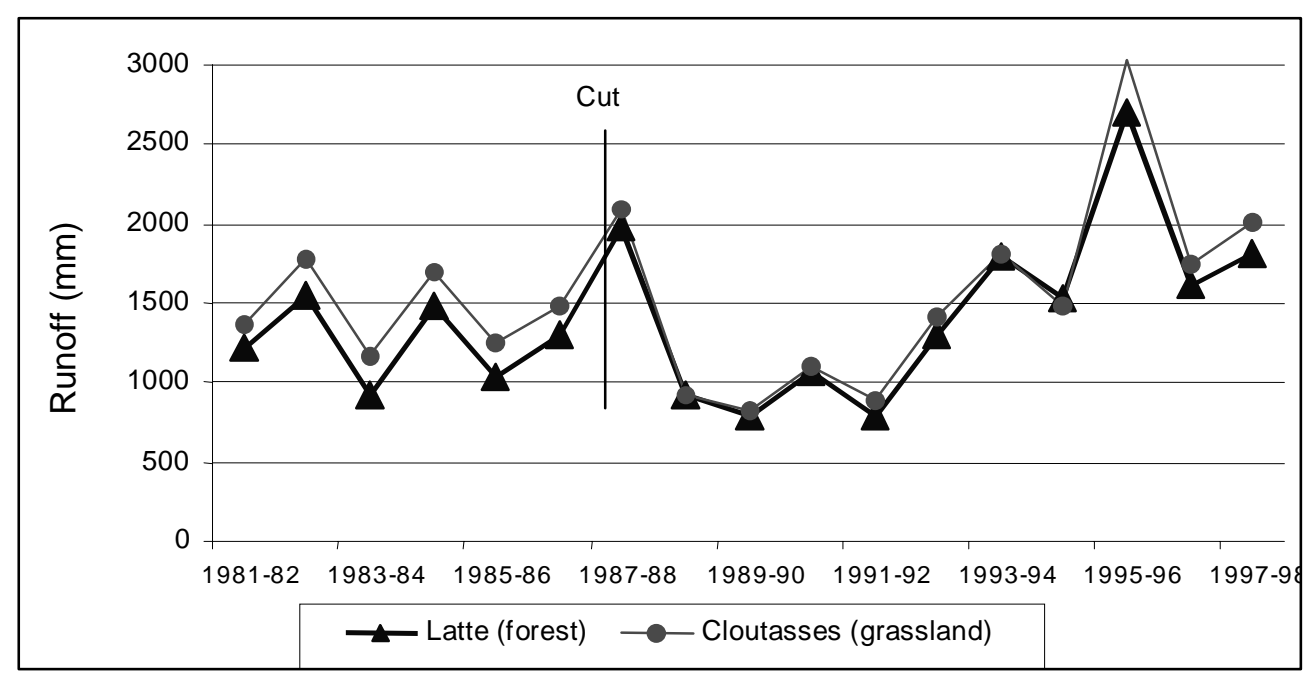

Figure 6 - Comparison of runoff on the Latte and Cloutasses catchments before and after forest cuts.

Before the cut, there was regularly less runoff on the Latte catchment than on the Cloutasses. After the cut, runoff values for both were the same or very close for a period of eight years, meaning that those for the cur over catchment (Latte) increased relative to the values for the reference one (Cloutasses). During the last three years of measurement, however, the runoff values for the Latte reduce again. This trend is also clearly observable when the cumulative daily discharge values for the Latte catchment are plotted against those for the Cloutasses reference catchment (Fig. 7).

The flow values measured after the cut are higher than those obtained by regression analysis using data gathered before the cut (Martin et al., 2000). Studies on runoff deficits give about the same results (Cosandey, 1993; Didon-Lescot, 1996), as do approaches using global conceptual models (as such the GR model used by Cognard-Plancq et al., 2001).

If one uses another reference catchment, the Sapine catchment (beech forest without change during the study period) instead of the Cloutasses catchment, the results also show positive differences between measured values and those computed using data from before the cut. However, the differences are smaller: annual runoff increases by only about 5\%. Because the Cloutasses catchment is closer than the Sapine catchment, we choose the first as a reference. But the gap between the two results gives an idea of the uncertainly concerning them.

This difference, which was not observed for the very heavy floods (see above), can be explained by a higher discharge for floods of average and small magnitude, due to the decrease in interception losses.

\subsection{Studies in the southern Massif Central}

It may be of interest to include the results of a study (Andréassian et al., 1999; Andréassian, 2002) that was not conducted in experimental basins, but also deals with the impact of forest on the hydrological behaviour of catchments. This study is based on 14 catchments of larger surface aera (Table 2) and used a longer period of observation (minimum 20 to 30 years, from 1960 to 1996). These catchments are all located along the 
southern edge of the Massif Central (Fig. 1). The Mediterranean climate there exhibits some mountain characteristics.

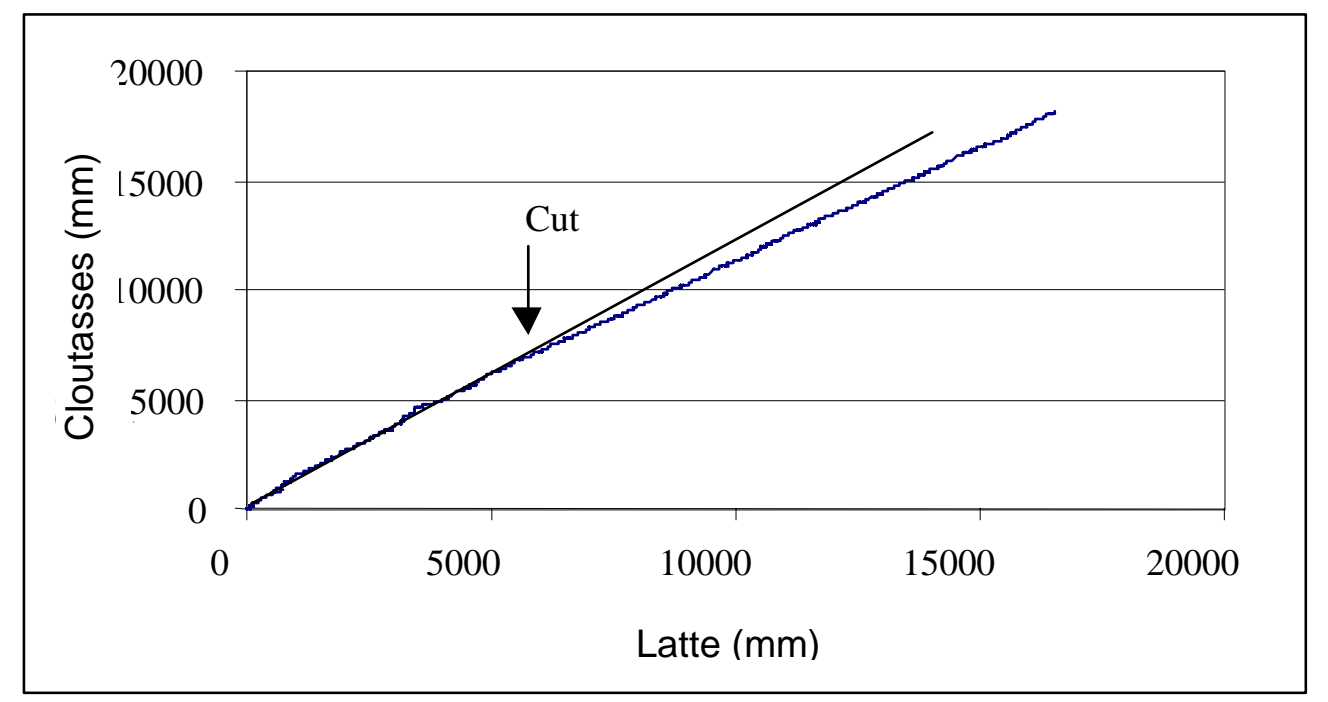

Figure 7 - Double mass curve for monthly runoff on the Latte and Cloutasses catchments from July 1981 through December 1998.

Table 2 - Observed trends in rainfall/discharge ratios for 14 study catchments in the Southern Massif Central.

\begin{tabular}{|c|c|c|c|c|c|c|c|}
\hline \multirow{2}{*}{ Catchment } & \multirow{2}{*}{$\left|\begin{array}{c}\text { Catchment } \\
\text { surface } \\
\text { area }\left(\mathrm{km}^{2}\right)\end{array}\right|$} & \multicolumn{2}{|c|}{$\begin{array}{l}\text { Average change to the } \\
\text { forest cover over the study } \\
\text { period }\end{array}$} & \multicolumn{4}{|c|}{$\begin{array}{l}\text { Apparent trend for each hydrological } \\
\text { characteristic: }\end{array}$} \\
\hline & & \begin{tabular}{|c|} 
'Surface \\
terrière'* \\
$\left(\mathrm{m}^{2} /\right.$ ha' year $)$ \\
\end{tabular} & $\begin{array}{c}\text { Timber } \\
\text { volume } \\
\left(\mathrm{m}^{3} / \mathrm{ha} / \text { year }\right)\end{array}$ & $\begin{array}{l}1 \text {-Total } \\
\text { runoff }\end{array}$ & $\begin{array}{l}2 \text { - Flood } \\
\text { flow }\end{array}$ & $\begin{array}{c}3 \text { - Low- } \\
\text { flow runoff } \\
\text { deficit }\end{array}$ & $\begin{array}{l}4 \text { - Base } \\
\text { flow }\end{array}$ \\
\hline $\begin{array}{l}\text { Goudesche at La } \\
\text { Cépède }\end{array}$ & 10 & +1.28 & +0.17 & 0 & 0 & 0 & 0 \\
\hline $\begin{array}{l}\text { Rieumalet at } \\
\text { Pont-de-Montvert }\end{array}$ & 20 & +0.35 & +0.05 & 0 & 0 & 0 & + \\
\hline Mirals at Rhunes & 12 & +0.85 & +0.11 & - & 0 & 0 & 0 \\
\hline Briançon at Cocurès 2 & 25 & +0.13 & +0.01 & 0 & 0 & - & + \\
\hline Brèze at Meyrueis & 36 & +0.67 & +0.08 & - & 0 & + & - \\
\hline Dourbie at Le Mazet & 43 & +0.73 & +0.04 & 0 & 0 & 0 & 0 \\
\hline Agout at Fraisse & 48 & +2.94 & +0.37 & 0 & 0 & 0 & + \\
\hline $\begin{array}{l}\text { Gardon de Saint-Martin } \\
\text { at La Roquette }\end{array}$ & 31 & +0.10 & +0.03 & 0 & 0 & 0 & o \\
\hline \begin{tabular}{|l|} 
Gardon de Saint- \\
Germain at La Bastide
\end{tabular} & 31 & +0.07 & +0.05 & 0 & 0 & 0 & 0 \\
\hline $\begin{array}{l}\text { Gardon de Sainte-Croix } \\
\text { at Gabriac }\end{array}$ & 33 & +0.08 & +0.01 & 0 & 0 & 0 & 0 \\
\hline Herault at Valleraugue & 46 & +0.14 & -0.07 & 0 & 0 & 0 & - \\
\hline $\begin{array}{l}\text { Gardon d'Alès at La } \\
\text { Farelle }\end{array}$ & 30 & +0.04 & +0.01 & 0 & 0 & - & 0 \\
\hline Tarn at Fontchalette & 67 & +0.49 & +0.06 & + & 0 & 0 & 0 \\
\hline Gagnière at Banne & 55 & +0.97 & +0.07 & - & 0 & + & - \\
\hline
\end{tabular}

+ : increase. -: decrease. 0 : little change.

*: 'Surface terrière' means the soil surface occupied by the alone trunks. 
The research revolved around four hydrological elements that are representative of the hydrological behaviour of a catchment. These elements are the following (see Figure 8):

1. Total runoff.

2. Flood flow (defined as runoff above a threshold equal to four times mean annual discharge).

3. Low-flow (defined as the runoff deficit below a threshold equal to one-fourth of mean annual discharge).

4. Base flow index (the index considered here corresponds to the ratio between base flow computed using the L'vovitch method (L'vovitch, 1979) and total flow).

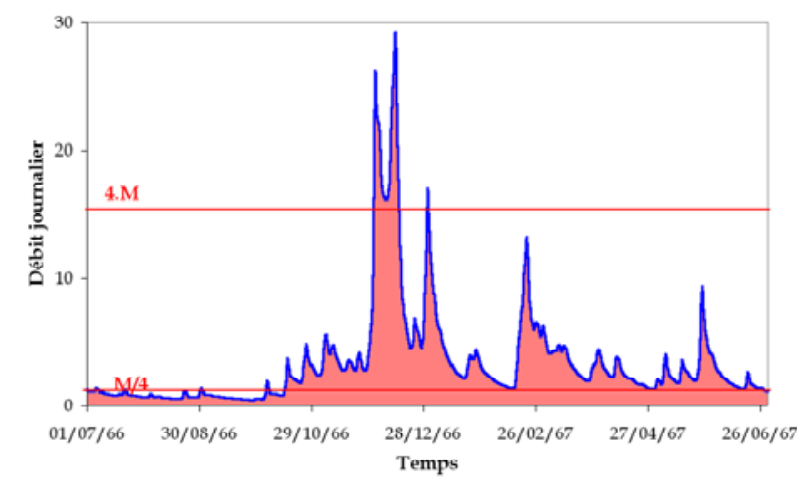

(1) Total Runoff

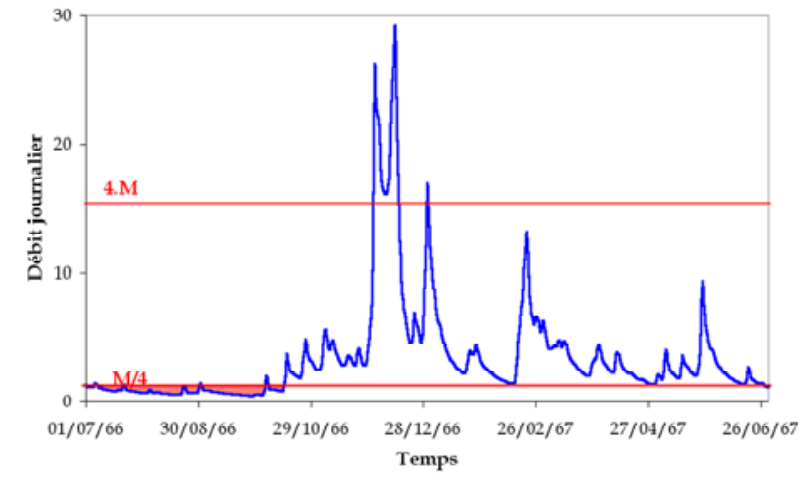

(3) Low-Flow Runoff Deficit

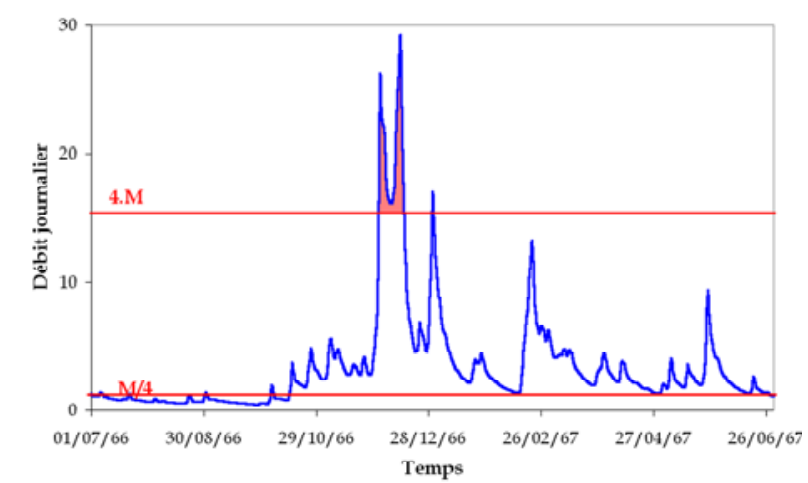

(2) Flood Flow

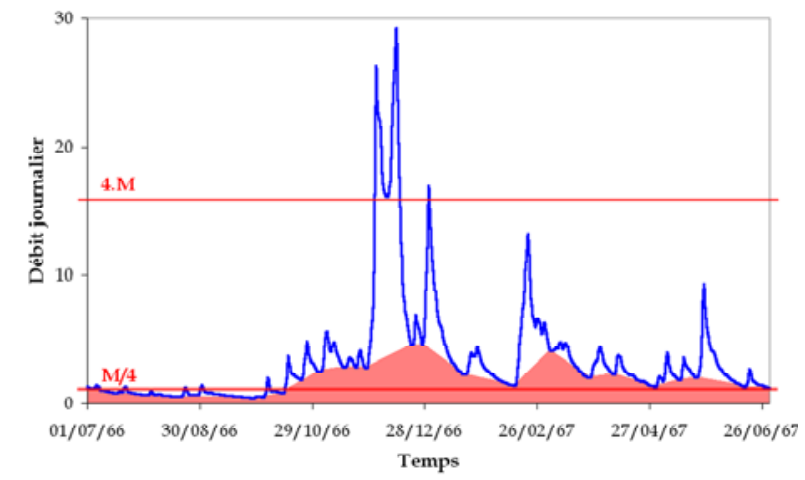

(4) Base Flow

Débit journalier : dayly discharge. Temps: time.

Figure 8: Hydrograph showing water levels for each one of the chosen hydrological elements. Horizontal lines $4 \mathrm{M}$ and $\mathrm{M} / 4$ represent the thresholds chosen to define flood (four times mean annual discharge) and low flow (one-fourth of mean annual discharge).

The study involved a joint analysis of the evolution of the forested surfaces and the four chosen hydrological characteristics:

- The trends for a given element were determined using a statistical test for non-stationarity presented by Andréassian (2002), setting the level of significance at 5\%.

- The evolution of the forest cover was determined using aerial photographs and French National Forest Survey statistical data (method presented by Muraz et al., 1999).

The group of study catchments showed a trend towards increased forest cover in terms both of surface and density. Insofar as this is consistent with the general trend of abandoned agricultural practices and regrowth of forest in the Massif Central as a whole, there is nothing in particular to add here. The trends for hydrological behaviour, however, are much less apparent (Table 2):

- For total runoff, only four catchments show a trend that is significant at the chosen level. The trend is negative in three out of four cases, which is consistent with the evolution that may be expected after a catchment is re-forested (Bosch and Hewlett, 1982). 
- For flood flow, no catchment shows a significant trend. In the short term (about thirty years), reforestation of these small catchments in the Southern Massif Central would apparently have no effect on flooding. We need to remember that flooding in this Cévennes/Montagne Noire region is the consequence of violent rainfall events in which, as hydrologists readily concur, the plant cover plays an insignificant role (Cosandey and Robinson, 2000; Cosandey, 1990).

- For the low-flow runoff deficit, only four catchments show a significant trend; these are positive in two cases (decreasing the flow even more) and negative in two. Therefore, it is not possible to arrive at a conclusion as to the effect on changes in forest cover.

- For base flow, six catchments show a significant trend. Here again, there is an equal positive/negative distribution, and it is not possible to arrive at a conclusion as to the effect on changes in forest cover.

In conclusion, the study apparently did not make it possible to establish a simple relationship between annual runoff and changes in forest cover in the Cévennes/Montagne Noire area. This may be explained by the high level of uncertainty, both for estimates of forested surfaces and for hydrological trends (in particular because of the uncertainty relative to estimating catchment rainfall). It might also indicate that the forest has a limited impact on the hydrological behaviour of the study catchments.

\section{5 - What can we conclude about the hydrological role of forests in Mediterranean climate?}

\subsection{The complex nature of the results obtained}

If we rely strictly on the set of results obtained during the above-described studies, we note that:

\subsubsection{For annual runoff}

Clear-cutting the forest increases annual runoff by about $10 \%$ on the Mont-Lozère catchments during the years immediately following the cut (but only by $5 \%$ if one uses a different reference catchment). This result is consistent with the observations of catchments throughout the world, widely reported on elsewhere (Bosch and Hewlett, 1982; Lavabre and Andréassian, 2000). On the Réal Collobrier catchments, there appears to be an identical trend after forest fire, but this is not clearly established. On the Draix catchments, the forest appears to decrease runoff, although the estimates are not very precise.

We also saw that the increase in forest cover observed over the last fifty years along the southern edge of the Massif Central has not significantly changed the amount of annual runoff. However, these catchments are considerably larger than our study catchments, and have not been subject to a sudden radical change in land use, but to a very progressive one.

\subsubsection{For floods}

The results obtained in the Draix basin are very clear with respect to floods: Flood flows on the forested catchment are $50 \%$ lower than those on the unforested ones; flood discharge is affected even more within the range of common frequencies since they are reduced fivefold.

In the Réal Collobrier basin, the forest fire on the Rimbaud catchment resulted in a clear, although temporary, increase in flood discharge (lasting only the first few years that followed the fire).

In the Mont-Lozère basin, there was no notable difference between pre- and post-clear cutting high flood discharge, although the average flows increased percepibly.

These results as summarized might appear to be at odds, and one might be led to think that it is difficult to reach any conclusions about the hydrological impact of the forest - all the more so that other studies (sometimes led by the same authors) on the same type of experiment or even based on the same set of data, also tend to show divided results. And yet, far from being divergent, these reported results are complementary. Their apparent contradictions are merely an indication of the complexity of the rainfall/discharge relationship. They are to be understood only if we take into account the specific impact of those factors (the nature and depth of the soils, the type of vegetation (when the study catchment is not a forested one), and the climatic conditions, among others) that determine not only evapotranspiration (and therefore annual runoff), but also the type and magnitude of floods. 


\subsection{The impact of the forest on rainfall/discharge relationships; theoretical considerations and discussion}

\subsubsection{Impact of the forest on annual runoff}

The forest has an effect on evaporation through two basic processes: (1) a more efficient use of soil moisture reserves during the summer months, and (2) the interception of a portion of incidental rainfall.

A more efficient use of the moisture reserves in forest soils presupposes relatively deep soils (otherwise the soil is taken up by root systems, even in the case of prairie vegetation or shrubs) and a large soil moisture deficit (Pe - P) in summer (otherwise, low soil moisture reserves are adequate for supplying plants with water), which is the case in Mediterranean climate. In the regions under study, the soil moisture deficit in summer is high. The soils, however, are relatively shallow except very localized, which limits summer evapotranspiration.

Interception losses are all the greater when rainfall is abundant but frequent and of low intensity. While the first condition is fulfilled well enough in the regions under study (our rain gauges register annual rainfall totals that always exceed $900 \mathrm{~mm} /$ year), the high intensity of Mediterranean storms is not conducive to interception losses.

These pedological and climatic conditions, therefore, do contribute to lessen the difference in values for evapotranspiration, and therefore for runoff, between forest vegetation and low vegetation.

We note that research on the impact of forest on flows generally shows that partial cutting has very little impact on evaporation, even in conditions where clear-cutting has a considerable one. The reason for this is that, in the case of partial cutting, overall interception losses remain high. Also, better circulation of wind through open forest is favourable to evaporation. The same cannot be said after a clear cut in a young growing forest, at least to the extent that it is too small to have acquired a large interception capacity and enough 'roughness to guarantee high air turbulence, and therefore efficient use of advective energy'. However, such specific circumstances are not identified per se in the present studies.

It is not surprising, therefore, that Andréassian's research in the southern Massif Central did not uncover a simple relationship between annual runoff and changes to the plant cover. And, although the experimental catchments studies do indicate a trend towards higher runoff on unforested catchments, when confirmed, it is slight ( $10 \%$ of annual runoff). It is clear that these results depend upon the percentage change in forest cover and so on the scale of observation - at the small scale, immediately downstream of a forest clear-felling, the effect is much larger than many km further downstream.

\subsubsection{Impact of forest vegetation on floods}

Floods are linked to a rapid circulation of water on the slopes, whether the circulation is surficial (surface runoff) or involves percolation down through the soil and rapid exfiltration of groundwater into streams as piston flow. The type of vegetation has little or no impact when the process is the result of deep underground circulation, but it influences surface runoff formation, as we shall see.

There are two types of surface runoff. One is excess infiltration overland flow, where infiltration cannot take place even though the soil is not saturated; the other is excess saturation overland flow, where infiltration cannot take place because the soil is saturated. The problem with this distinction is that it does not differentiate between Hortonian surface runoff, where low infiltration rates are linked to the low intrinsic permeability of the soil, and surface runoff resulting from the sometimes very rapid changes brought about by heavy rainfall to the condition of soil surfaces that have scant protection from vegetation. ${ }^{1}$

We also note that forests modify the hydrodynamic characteristics of forest soils (which constitute an essential component of the hydrological behaviour of forested catchments during floods) by influencing their structure and stability at different levels, directly or indirectly. Since forest soil can take a long time to build up, the effects of afforestation or deforestation can be limited because the nature of the soil has not changed. When it is not accompanied by a preparation of the land for culture or soil erosion, deforestation does not necessarily lead to a significant aggravation of flooding, especially when replacement vegetation grows rapidly and densely. This is what was observed on Mont-Lozère - although it is true that the rainfall and

\footnotetext{
${ }^{1}$ The particles at the surface can become re-organized under the influence of heavy rain and rain splash, leading to rainbeat crust, for example, or raindrop impact erosion.
} 
pedological conditions there are rather specific (very abundant precipitation that minimises the attenuating role of the forest on floods, and highly permeable soils that prevent surface runoff by infiltraton excess).

\subsubsection{Impact on flood volume}

In all cases, interception of a portion of incidental rainfall by forest vegetation (for which the interception capacity is higher than any other type of vegetation) decreases the rainfall that reaches the soil by the same amount. However, interception losses are proportionally lower during the type of heavy rainfall that causes floods; on Mont-Lozère, the forest has a limited impact in the case of very heavy floods, whereas its effect has been confirmed when flood flows are lower.

In the case of Hortonian surface runoff on more impervious soils, the forest changes the soil structure, increasing the infiltration capacity. Once acquired, the new soil characteristics persist independently of the vegetation cover, sometimes long after deforestation.

When the surface runoff is the result of changes in the soil surface linked to splash, trees and litter provide no better protection than other types of adequate plant cover. On the other hand, if forest cuts leave the ground bare (which is not the case on Mont-Lozère) or if fire completely destroys the vegetation (which is what happened on the Rimbaud catchment), the poorly protected soil is vulnerable to a modification of the soil surface by splash. These modifications can trigger surface runoff that never occurred before, which is a possible explanation for the flooding characteristics on the Rimbaud catchment immediately following the forest fire.

When the surface runoff is caused by saturation due to a rise in the water table, the type of cover is not a direct factor in the increase of saturated surface during the rainfall - and therefore not in the runoff coefficient, either. However, cover type may have an effect on the state of the hydrologic reserves through the interception process, which may reduce the amount of water that reaches the water table.

Forestation is often accompanied by a resumption of streambed erosion linked to the decrease in sediment load from slopes. If the geomorphological conditions lend themselves to it, the bed can sink down (Bravard, 1993). Since a sinking streambed contributes to lower the water table, it can limit the extension of the saturated surfaces and the magnitude of the floods such surfaces are capable of generating.

\subsubsection{Impact on flood peaks}

For a given catchment, flood magnitude depends on the rapidity of flow concentration. It is often considered that by slowing down the circulation of surface runoff, forest vegetation also slows down concentration times. But forest vegetation has more or less the same effect as with other types of vegetation - grassland, in particular. Here again, the main difference is between bare soil and vegetated soil, rather than between one type of vegetation and another.

In the case of water transfer to the stream as mainly the result of subsurface processes, one might think that forest soils, which usually have a highly permeable structure, would affect the transfer of pressure and/or the water circulation rates in the soil. However, all authors do not agree on this point (Rawling et al., 1997).

A final point is, as seen about, that, by reducing sediment load in streams, forestation can speed up linear erosion. In certain geomorphological conditions, this development is likely to increase the downward slope of thalwegs. The resulting faster evacuation of floods that results (Arnaud-Fassetta et al., 1993) can have an effect on downstream concentration rates.

\section{6 - Discussion}

What emerges from these different reports is that forest appears to decrease flood peaks in certain conditions, but to have no particular effect in others, at least compared to any other type of healthy vegetation that covers the ground. Given all these considerations, it is easy to understand the wide range of results obtained.

First of all, it is noteworthy that the experimental protocol differed in all three basins. In the Mont-Lozère and Réal Collobrier basins, deforestation is involved, meaning that the original forest soil does exist and continues to have a hydrological impact; in the unforested Draix basin, there is no initial forest soil. However, deforestation by forest fire and deforestation by forest cut do not have the same impact. The fire denudes the soil completely, and the extreme heat can result in changes to the soil surface; as a result, surface 
runoff can occur if raindrop impact leads to the formation of splash crust. Forest cuts leave the soil protected by the branches of felled trees (only the trunks are taken out), so conditions are hardly favourable for surface runoff.

Rainfall and floods do not have the same impact, either. In spite of the much heavier rainfalls in the Mont-Lozère basin, where the observed daily maxima are close to $400 \mathrm{~mm}$ (in the Réal Collobrier basin, they are only $150 \mathrm{~mm}$, and in the Draix, $80 \mathrm{~mm}$ for decadal rainfall), flood peaks on Mont-Lozère's Cloutasses grassland catchment are much lower than the discharge recorded on the Réal Collobrier's Rimbaud catchment and the Draix's Laval catchment, both without forest. The reason for this is that the soils on the Cloutasse are highly permeable and well-protected by vegetation, contributing to surface runoff only when they are completely saturated. Therefore, here, it would appear that the hydrological behaviour of a grassland catchment is no different than that of a forested catchment.

Given these conditions, we can understand that cutting down trees on the Latte catchment had little impact. Thanks to the abundant rainfall on Mont-Lozère's forested catchment, however, interception by the forest considerably reduced the portion of rainfall reaching the soil - and reduced flows by almost as much. This loss by interception (varying from one to several mm per day) explains the much higher discharge for floods generating flows lower than $5 \mathrm{~mm} /$ day, which are frequent in the Mont-Lozère basin.

The factor that determines very different hydrological processes is almost always bare soil vs. covered soil, rather than forest vs. other type of vegetation. Therefore, understanding and being able to forecast the impact of forestation on hydrology requires identifying the specific flow formation processes in the region under study. Only then will it be possible to determine whether or not these processes risk being changed by deforestation or afforestation.

\section{7 - General conclusion}

The studies carried out in France on forest hydrology in Mediterranean climate have demonstrated that the role forests play with respect to runoff is complex indeed. Considering that forests have no impact on flooding would be just as erroneous as to affirm that forests reduce floods systematically.

The complexity of rainfall/discharge relationships is such that it is not possible to forecast the impact of afforestation or deforestation without understanding the hydrological behaviour of the environment under consideration. The behaviour depends on the soils, climatic conditions, and vegetation characteristics, among other things.

It is also useful to remember that the uncertainty of the source data (rainfall and discharge) used for analysis is often probably about as great as the impact of the parameters we are trying to estimate (in this case, the role of vegetation), not to mention the uncertainty in model assumptions. It is possible, however, to draw a few conclusions from the synthesis:

- Bare soil vs. covered soil is the important factor, rather than forest vs. any other type of vegetation. If clearing land usually causes significant disturbance to the environment, it is because crops that leave the soil bare for a good part of the year usually replace the forest. The effects of the Rimbaud fire on floods faded as soon as the soil was recolonized by shrub vegetation. In the Mont-Lozère basin, the grassland catchment behaved pretty much in the same way as the forested ones (except for a slight difference in annual runoff), in contrast to the situation in the Draix basin, where the poorly covered Laval catchment and the forested Brusquet catchment exhibited radically different hydrological behaviour.

- It is important to note the importance of forest soil. The fact that it remains after the trees are gone can explain why deforestation has so little impact, even if forest soil still must be considered as a creation of the forest.

- In conclusion, while the impact of forest can sometimes be considerable, it is far from being significant in every case. By no means the least important result of the research done by Andréassian et al. (1999) is to have demonstrated that the current management of forests on the Mediterranean side of the Massif 
Central has no more than a very slight impact on the hydrological behaviour of the catchments there, and that this impact (if it really does exist) is completely overshadowed by the climate variability.

\section{References}

Andréassian, V., 2002. Impact de l'évolution du couvert forestier sur le comportement hydrologique des bassins versants. Ph.D. Thesis, Université Pierre et Marie Curie, Paris.

Andréassian (Coordinateur), V., Tangara, M., Muraz, J., Caugant, C., Cosandey, C., Dérioz, P., Laques, A.E., Bourreau, J.G., Didon, E., Durrieu, S., Hamza, N., 1999 - Indicateur d'impact de l'évolution du couvert forestier sur la ressource en eau à l'échelle des bassins versants des Cévennes et de la Montagne noire. Rapport de recherches du programme "Environnement, Vie et Sociétés du CNRS."

Arnaud-Fassetta, G., Ballais, J.L., Béguin, E., Jorda, M., Meffre, J.C., Provansal, M., Roditis, J.C., Suanez, S., 1993 - La crue de l'Ouvèze à Vaison-la-Romaine (22.09.92). Ses effets morphodynamiques, sa place dans le fonctionnement d'un géosystème anthropisé. Rev. Géomorph. Dyn., t. XLII, nº 2, pp 34-48.

Ballais, J.L., 1997 - Apparition et évolution de roubines à Draix. Actes du séminaire "Les bassins versants expérimentaux de Draix, laboratoire d'étude de l'érosion en montagne" (Draix, Le Brusquet, Digne, 1997), Cemagref-Editions, coll. Actes de colloques, Mathys N. édit., pp 235-245.

Bravard, J.P., 1993 - L'incision des lits fluviaux : du phénomène morphodynamique naturel et réversible aux impacts irréversibles. Rev. Géogr. Lyon, vol. 69, n 1, pp 5-10.

Bosch, J.M., Hewlett, J.D., 1982 - A review of catchment experiments to determine the effect of vegetation on water yield and evapotranspiration. J. Hydrol., vol. 55, pp. 3-23.

Bruijnzeel, L.A., 1990 - Hydrology of moist tropical forests and effects of conversion: a state of knowledge review. UNESCO, I.H.A.P. publication of the Humid Tropics Programme.

Cognard-Plancq, A.L., Marc, V., Didon-Lescot, J.F., Normand, M., 2001 - The role of forest cover on streamflows down sub-Mediterranean mountain watersheds: a modelling approach. J. Hydrol., vol. 254, pp. 229-243.

Combes, F., Hurand, A., Meunier, M., 1994 - La forêt de montagne : un remède aux crues. Actes des $23^{\text {èmes }}$ Journées de l'Hydraulique "Crues et inondations" (Nîmes, 1994), Edit. SHF, pp 475-480.

Cosandey, C., 1990. Etude des crues Cévenoles : conditions d'apparition dans un petit bassin versant forestier sur le versant sud du Mont Lozère. IAHS Publication, n 191, pp. 103-115.

Cosandey, C., 1993 - Conséquences hydrologiques d'une coupe forestière. Le cas du bassin de la Latte (Mont-Lozère, France). In : L'eau, la terre et les hommes, Hommage à René Frécaut, Griselin M. édit., Presses Universitaires de Nancy, pp 355-363.

Cosandey, C., 1994 - Formation des crues "cévenoles" dans des bassins élémentaires du Mont Lozère. Revue des Sciences de l'Eau, vol. 7, pp 377-393.

Cosandey, C, Martin, C., Didon-Lescot, J.F., 2000 - Forêt et écoulements : étude des conséquences d'une coupe forestière sur le bilan d'écoulement annuel, les crues et les étiages. Rapport sectoriel pour le rapport final du contrat européen FOREX, 34 p.

Cosandey, C., Robinson, M., 2000. Hydrologie continentale. Armand Colin, Paris, 360 p.

Didon-Lescot J.F., 1996 - Forêt et développement durable au Mont-Lozère. Impact d'une plantation de résineux, de sa coupe et de son remplacement, sur l'eau et sur les réserves minérales du sol. Thèse de Doctorat de l'Université d'Orléans, 161 p + bibliographie et annexes.

Fourcade, B., 2001 - Fonctionnement hydrologique et hydrochimique d'un petit bassin versant méditerranéen. Conséquences de la variabilité hydrologique et d'un incendie de forêt (bassin du Rimbaud, Réal Collobrier, Var). Thèse de l'Université Montpellier II, 181 p.

Fritsch, J.M., 1992 - Les effets du défrichement de la forêt amazonienne et de la mise en culture sur l'hydrologie de petits bassins versants. Collection Etudes et Thèses, ORSTOM, Paris, 1992, 391 p. 
Hazen, A., 1930 - Flood flows, a study of frequencies and magnitudes. Edit. Wiley, New-York.

Lavabre, J., Folton, N., Arnaud, P., Martin, C., 1999a - Impact d'un incendie de forêt sur l'hydrologie d'un petit bassin versant méditerranéen. Incertitudes liées à la méthodologie d'analyse et à la métrologie. Actes du séminaire "Les bassins versants expérimentaux de Draix, laboratoire d'étude de l'érosion en montagne" (Draix, Le Brusquet, Digne, 1997), Cemagref-Editions, coll. Actes de colloques, Mathys N. édit., pp 41-52.

Lavabre, J., Martin, C., avec la collaboration de Didon-Lescot J.F., 1999b - Appréciation de l'impact des coupes forestières sur l'hydrologie et l'érosion des sols. Cas de la forêt d'Altefage (commune du Pontde-Montvert - 48). Rapport à la DDAF de Lozère, Edit. Cemagref, Aix-en-Provence, 28 p.

Lavabre, J., Andréassian, V., avec la collaboration de Laroussinie, O., 2000a - Eaux et Forêts. La forêt. Un outil de gestion des eaux. Cemagref Editions, coll. Ecosystèmes Forestiers, nº 1, 116 p.

Lavabre, J., Martin, C., Folton, N., 2000 b - Impact de l'incendie sur le comportement hydrologique du bassin versant. Chapitre III. In : Conséquences d'un incendie de forêt dans le bassin versant du Rimbaud (massif des Maures, Var, France): destruction et régénération du couvert végétal, impacts sur l'hydrologie, l'hydrochimie et les phénomènes d'érosion mécanique. Cemagref Editions, Coll. Etudes Gestion des milieux aquatiques, n 16, Martin C. et Lavabre J. édit., pp 33-49.

L'vovitch, M.I., 1979 - World water resources and their future. American Geophysical Union, Washington

Martin, C., Lavabre, J., 1997 - Estimation de la part du ruissellement sur les versants dans les crues du ruisseau du Rimbaud (massif des Maures, Var, France) après l'incendie de forêt d'août 1990. Journal des Sciences Hydrologiques, vol. 42, n 6, pp 893-907.

Martin, C., Didon-Lescot, J.F., avec la collaboration de Cosandey, C., 2000 - Le rôle du couvet végétal sur le fonctionnement hydrologique des bassins versants expérimentaux du Mont-Lozère. In : Etude intégrée du bassin versant du Haut-Tarn appliquée à la gestion des ressources en eau et des fonctionnements hydrobiologiques: contribution de l'UMR "ESPACE" à la connaissance des fonctionnements hydrologiques et hydrochimiques, Rapport intermédiaire pour le Parc national des Cévennes et l'Agence de l'Eau Adour-Garonne, pp 34-53.

Muraz, J., Durrieu, S., Labbé, S., Andréassian, V., Tangara, M., 1999 - Comment valoriser les photos aériennes dans les SIG? Ingénieries - EAT, vol. 20, pp. 39-58.

Poiniard, D., 2000 - Analyse hydrologique de deux bassins montagneux à couvert végétal contrasté. DEA, Université d'Avignon, $42 \mathrm{p}$ + Annexes.

Puech, C., Viné, P., Leibreich, J., 1994 - Evolution comparée entre variations d'écoulement et couvert végétal suite à incendie. Réal Collobrier 1990-1993. Actes du Workshop Final du Projet Européen DM2E (Barcelone, 1994), Edit. Cemagref, 10 p.

Rawlins, B.G., Baird, A.J., Trudgll, S.T., Hornung, M., 1997 - Absence of preferencial flows in the percolating waters of a coniferous forest soil. Hydrol. Process, vol 11, pp. 575-585.

Richard, D., Mathys N., 1999 - Historique, contexte technique et scientifique des BVRE de Draix. Caractéristiques, données disponibles et principaux résultats acquis au cours des dix ans de suivi. Actes du séminaire "Les bassins versants expérimentaux de Draix, laboratoire d'étude de l'érosion en montagne" (Draix, Le Brusquet, Digne, 1997), Cemagref-Editions, coll. Actes de colloques, Mathys N. édit., pp 11-28.

Viné P., 1997 - Identification de l'hétérogénéité spatio-temporelle des comportements hydrologiques. Apports de la télédétection satellitale. Application aux bassins versants du Réal Collobrier (France) et de la Mare d'Oursi (Burkina-Faso). Thèse de Doctorat de l'Université J. Fourier - Grenoble I, 285 p. 